The Other Side of Medical Care 


\section{The 'New Approaches to Care' series}

Patients are people. They have feelings, families and fears. Whatever the cause for their seeking help, the caring professional will find that he or she will be concerned with these other issues. All illness carries with it anxiety and each person has very individual and important feelings about it; feelings which can easily be forgotten or neglected when nurses become preoccupied with the details of treatments, procedures and ward routines.

The New Approaches to Care series aims to explore this 'other side' of care in a practical and realistic way, emphasising the importance of meeting all the patients' needs, while recognising the constraints and problems which so often make the 'other side' the forgotten side of patient care.

The books in this series examine the implications that treatments, procedures, investigations and routines can have for patients and their families. They also aim to help nurses gain some insight into the problems, feelings and anxieties which people can experience when they are being looked after in hospital or the community. The series will thus offer a tangible starting point for all nurses and other professionals, both in training and in practice, to give their patients the most complete and understanding care possible.

\section{Series Editors}

June Jolly, SRN, RSCN, has devoted most of her nursing career to the care of sick children, and was involved with establishing a new paediatric unit at Brook General Hospital, Woolwich.

Jill Macleod Clark, BSc, PhD, SRN, is a Lecturer in the Department of Nursing Studies, Chelsea College, University of London.

Will Bridge, BSC, PhD, is the Co-ordinator of the Learning Resources Unit at Brighton Polytechnic. 
Other titles in this series

The Other Side of Growing Older Pat Brown

The Other Side of Paediatrics June Jolly

The Other Side of Psychiatric Care Margaret Garland

The Other Side of Surgery Janet Gooch 
The tender word forgotten, The letter you did not write, The flower you might have sent, dear, Are your haunting ghosts tonight.

Margaret Sangster (1838-1912), At Sunset

To B.S. - without her unfailing support this book would never have been written. 


\title{
The Other Side of Medical Care
}

\section{Carol Flemming}

\author{
Illustrated by \\ Gillian Symonds, ARCA
}

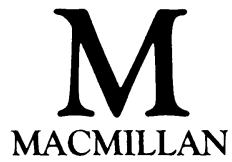


(c) Carol Flemming 1986

All rights reserved. No reproduction, copy or transmission of this publication may be made without written permission.

No paragraph of this publication may be reproduced, copied or transmitted save with written permission or in accordance with the provisions of the Copyright Act 1956 (as amended).

Any person who does any unauthorised act in relation to this publication may be liable to criminal prosecution and civil claims for damages.

First published 1986

Published by

MACMILLAN EDUCATION LTD

Houndmills, Basingstoke, Hampshire RG21 2XS

and London

Companies and representatives

throughout the world

Typeset by TecSet Ltd, Sutton, Surrey

British Library Cataloguing in Publication Data

Flemming, Carol

The other side of medical care. - (New approaches

to care)

1. Hospital care

I. Title II. Series

362.1'1 RA971

ISBN 978-0-333-37528-0 ISBN 978-1-349-18179-7 (eBook)

DOI 10.1007/978-1-349-18179-7 


\section{Contents}

Preface

Foreword

$\mathrm{xi}$

Acknowledgements

1 The Changing Face of Medical Nursing 1

Introduction 1

Historical changes 1

Changing trends in patient expectation 3

Technological advance 4

Home can be better $\quad 6$

Bridging the gap between hospital and community $\quad 7$

Hospital admission $\quad 8$

$\begin{array}{ll}\text { References } & 8\end{array}$

Bibliography $\quad 9$

2 Caring for Needs $\quad 10$

Introduction $\quad 10$

Physiological needs $\quad 12$

Food 13

Sleep $\quad 17$

Difficult needs to express $\quad 20$

The need for contact $\quad 21$

The need for understanding 24

$\begin{array}{ll}\text { The need to touch } & 27\end{array}$

The need to be cared for $\quad 28$

Needs we don't like to talk about 29

References $\quad 30$

Bibliography $\quad 30$ 
3 The Patient and His Family 32

Introduction $\quad 32$

The role of the patient $\quad 32$

Family or visitors? $\quad 34$

Nurses and visitors $\quad 34$

Extending the role of the family 38

$\begin{array}{ll}\text { Practical points } & 39\end{array}$

4 Caring with and without Words 42

Introduction $\quad 42$

Communication $\quad 42$

Verbal communication $\quad 44$

Non-verbal communication $\quad 46$

Actually talking $\quad 49$

Communicating with the ward team 51

References $\quad 54$

Bibliography $\quad 55$

5 Sharing Caring $\quad 56$

Introduction $\quad 56$

The ward environment $\quad 57$

Team identity $\quad 59$

A united front $\quad 59$

Teaching $\quad 59$

Nurse counselling $\quad 63$

References $\quad 63$

Bibliography $\quad 64$

6 Caring for the Dying 65

Introduction $\quad 65$

Terminal illness on the general ward $\quad 65$

The staff $\quad 65$

$\begin{array}{ll}\text { The patient } & 67\end{array}$

The family $\quad 68$

Death and dying in hospital $\quad 70$

$\begin{array}{ll}\text { Preparation } & 70\end{array}$

Breaking the news $\quad 71$

$\begin{array}{ll}\text { Teamwork } & 73\end{array}$

Home to die $\quad 74$

References $\quad 74$

Bibliography $\quad 75$ 
7 Caring in Times of Stress 77

Introduction $\quad 77$

$\begin{array}{ll}\text { Extraordinary people } & 77\end{array}$

Acute emergencies $\quad 82$

Cardiac arrest $\quad 82$

Other emergencies $\quad 83$

$\begin{array}{ll}\text { Coping as a team } & 84\end{array}$

With one another $\quad 84$

With the family $\quad 85$

References $\quad 85$

Bibliography $\quad 86$

8 Going Home $\quad 87$

$\begin{array}{ll}\text { Introduction } & 87\end{array}$

Returning home $\quad 87$

$\begin{array}{ll}\text { Taking drugs } & 89\end{array}$

Out-patients' clinics $\quad 91$

Special discharge advice $\quad 93$

Anticoagulants $\quad 93$

Myocardial infarction $\quad 93$

Pacemakers $\quad 95$

$\begin{array}{ll}\text { Bibliography } & 96\end{array}$

9 Hope for the Chronically Ill 97

$\begin{array}{ll}\text { Introduction } & 97\end{array}$

Help available $\quad 97$

$\begin{array}{lr}\text { In-patients } & 97\end{array}$

Out-patients 101

The chronically ill 102

Renal failure $\quad 102$

Oncology 103

Cardiopulmonary disease $\quad 104$

Disabled $\quad 105$

Diabetes $\quad 106$

Hope for the future $\quad 108$

$\begin{array}{ll}\text { References } & 108\end{array}$

$\begin{array}{ll}\text { Bibliography } & 108\end{array}$

10 Two Faces of Medical Care 109

$\begin{array}{ll}\text { Useful Addresses } & 112\end{array}$ 


\section{Preface}

This book is one of a series about people. People who find themselves, for whatever reason, dependent upon others as they recover from illness.

The purpose of this series, called 'New Approaches to Care', is to demonstrate that all patients, no matter how old or young, are individuals and that nurses have a responsibility to maintain their patients' self-respect and to give them the best care possible. June Jolly started the series with The Other Side of Paediatrics, concentrating on the needs of children in hospital; this was followed by Pat Brown's The Other Side of Growing Older, moving the emphasis to those 'at the other end' of their life. Margaret Garland wrote The Other Side of Psychiatric Care, which was followed by The Other Side of Surgery, by Janet Gooch. Throughout the series there have been many examples of many people whose lives have been disrupted by illness.

Most patients find hospital admission a traumatic experience and most medical conditions are frightening in themselves, perhaps because of pain or fear of what the diagnosis might be, or the threat to one's independence in the face of ill health. Many of the people I have described in this book have had to face a future of ill health as well, for many medical conditions do not 'get better': they can only be controlled. This is the challenge to all nurses involved in this field - to show compassion and humanity to the many people requiring care for however long the illness may continue.

My own belief is that the nurse is there to help the patient and his family - together - to cope with illness and recovery. I would be the first to agree that this demands much more 
from the nurse than the old system of 'getting the job done', but $I$ insist that the nurse and the patient together will find greater rewards.

Throughout the book the unnamed patient is referred to as 'he', merely for ease of expression and the convenience of readers. For the same reason all staff are referred to in the female gender.

Brighton, 1985 C.A.F . 


\section{Foreword}

I consider it a privilege to be asked to write the foreword for this book. Carol Flemming believes deeply in the need to nurse patients as individual people with unique needs. In this text she has responded to the challenge to explain that belief as it relates to the patients in medical wards. The combination of medical nursing and her commitment to patients as people makes the book unique.

She asks the reader to accept the deeper involvement with patients and their families that is essential to an understanding of their true needs. She recognises the feelings of nurses within such relationships and offers support by that understanding. She shares the insight developed in her experience as a staff nurse and a ward sister in such a way that learners will be stimulated into trying to emulate her really caring approach.

The text presents its important information in a manner that is easily read and understood. I am sure that any nurses involved in this field will find it valuable - whether they be ward staff, managers or teachers.

The author is a valued colleague and I wish her every success with this her first book.

Janet Gooch 


\section{Acknowledgements}

So many people have contributed to the making of this book directly and indirectly, and I wish to thank them. This is by no means a complete list.

It is largely due to Janet Gooch, who wrote The Other Side of Surgery, that this book ever came to be written, and she has continually offered her experience and support. June Jolly, author of The Other Side of Paediatrics, has helped shape ideas into the written word. Elizabeth Horne, then Macmillans' nursing editor, never failed to restock my failing enthusiasm, and this task has now passed on to Mary Hoddinott. It has been a great pleasure to meet and work with Gillian Simmonds, the artist, and I am much indebted to her for bringing to life so vividly some of the concepts I have tried to express.

To Eric Evans, my nurse tutor of many years ago, I give thanks for teaching me that learning can be fun. Alan Boylan, Tina Poxon and Margaret Deans from the Brighton School of Nursing have helped me work out in practice the theory that patients are the most important people on the ward. Sue Marshall, Superintendent Physiotherapist, and Lesley Watson, Occupational Therapist, have given me invaluable help with Chapter 9. A special 'thank you' to Bonnie, who has so patiently read and reread manuscripts and has offered so much encouragement.

This is very much a practical book, written from experience, and there would be no experience but for the patients I have had the privilege to meet over the years. It is for them, and for those who will continue to care for them, that this book is written. 